УДК 616.24-002.151 + 616.381-002.1

DOI 10.11603/2414-4533.2021.2.12307

(СА. Ю. ГОРОлюК

НКП "Криворізька міська лікарня № 7" Криворізької міської ради

\title{
Серозно-фрібринозний перитоніт як казуїстичний клінічний прояв нової коронавірусної хвороби SARS-CoV-2 COVID-19
}

Мета роботи: розглянути рідкісний випадок розвитку перитоніту як казуїстичний прояв нової коронавірусної хвороби SARSCoV-2 COVID-19.

Ключові слова: коронавірусна хвороба SARS-CoV-2 COVID-19; перитоніт; серозно-фібринозний перитоніт.

Серед клінічних проявів коронавірусної хвороби COVID-19, яку спричиняють раніше невідомий бета-коронавірус SARS-CoV-2, рідко зустрічаються повідомлення про розвиток серозного перитоніту. При огляді доступних джерел інформації (наукові англомовні, німецькомовні, україномовні та російськомовні журнали та наукові інтернет-повідомлення), можемо вказати, що 3 моменту пандемії нової коронавірусної хвороби COVID-19 було встановлено лише п'ять випадків розвитку перитоніту як безпосередньо результату коронавірусної інфекції SARS-CoV-2. Три випадки були описані в англомовних наукових часописах, два інші зафіксовані на території Російської Федерації. Розвиток перитоніту в цих хворих не був пов'язаний безпосередньо із гострою хірургічною патологією органів черевної порожнини. За даними великобританського часопису Experimental and Therapeutic Medicine/ Acute surgical abdomen during the COVID-19 pandemie: clinical and Therapeutic challenges (published online on: March 22, 2021), механізми абдомінального болю при інфекції SARS-CoV-2 можна поділити на легеневі (з аномаліями підтвердженими на комп'ютерній томограмі), внаслідок ураження нижніх часток легень та позалегеневі, які можуть бути тромботичними та нетромботичними. Тромботичні причини можна пов'язати із прямою інвазією вірусами рецепторів ангіотензинперетворювального фермента (АПФ) в ендотелії судин, прямою вірусною інвазією кровоносних судин або оклюзією, внаслідок утворення мікротромбів, що зумовлює мезентеріальну ішемію (оклюзійну або неоклюзійну), інфаркти ниркових судин, судин сальника. Нетромботичні причини, описані у літературі, охоплюють панкреатит, перитоніт, здуття товстої кишки і коліт та пов'язані із тропізмом вірусу до рецепторів АПФ у травному тракті.

Наводимо власне спостереження випадку казуїстичного розвитку перитоніту у хворої на COVID-19.
Хвора В., 55 років, перебувала на лікуванні в хірургічному відділенні КНП "Криворізька міська лікарня № 7” КМР з 25.04.20 13 год 23 хв до 26.04.20 10 год 36 хв. Доставлена бригадою екстреної (швидкої) медичної допомоги через переведення з міської лікарні № 8 м. Кривий Ріг, де перебувала на стаціонарному лікуванні. Скарги на інтенсивний біль у животі, задишку, загальну слабість.

За тяжкістю стану хворої анамнез встановлено на підставі виписного епікрізу Криворізької міської лікарні № 8 та частково зі слів родичів пацієнтки. Скарги на загальну слабість, запаморочення, головний біль, сухий кашель у хворої 3'явились близько 10 днів тому. Контакти з особами, що впродовж останніх 14 днів повернулись 3-за кордону (в умовах оголошеної ВООЗ пандемії COVID-19), родичі хворої заперечували. У зв'язку із прогресивним погіршенням стану хворої (різка загальна слабксть, розлади свідомості, запаморочення), родичі 18.04 .20 р. викликали бригаду екстренної (швидкої) медичної допомоги, хвору госпіталізували до Криворізької міської лікарні № 4 за місцем проживання. 18.04.20 р. одразу після госпіталізації, пацієнтку протестовано на антитіла до COVID-19, результат негативний, після чого госпіталізована до терапевтичного відділення з підозрою на енцефалопатію невідомого генезу. Виконана селективна комп'ютерна томографія (СКТ) головного мозку та грудної клітки. Заключення СКТ головного мозку: “Об’ємної та вогнищевої патології головного мозку не виявлено. Кістково-деструктивної патології не виявлено. СКТ-картина ДЕП 2 ст.”. Заключення СКТ грудної клітки: “Захворювання правої молочної залози. Вторинна верхньо-часточкова пневмонія справа”. 3 18.04.20 р. до 20.04.20 р. пацієнтка перебувала на стаціонарному лікуванні в терапевтичному відділенні Криворізької міської лікарні № 4 здіагнозом: “Захворювання правої молочної залози, метастази в органи грудної клітки. ДЕП, лікворо- 
динамічний, інтоксикаційний синдром, сопор. Гіпертонічна хвороба 2 ст., ризик 4, СН 1 ст.”. Незважаючи на лікувальні заходи стан хворої продовжував прогресивно погіршуватись, рівень свідомості - сопор, прогресували явища інтоксикації, дихальної недостатності. Для подальшого лікування хвору 20.04.20 р. перевели у відділення реанімації Криворізької міської лікарні № 8. Рентгенографія органів грудної клітки від 20.04.20 р.: “Справа на верхівці ділянка неоднорідного затемнення легеневої тканини без чітких контурів, корені зниженої структурності, синуси вільні. Висновок: пневмонія справа при наявності клініки, при відсутності - не виключені метастази справа”. ЕКГ 20.04.20 р. синусова тахікардія, метаболічні зміни міокарда. 22.04.20 р. проведено СКТ органів грудної клітки, органів черевної порожнини, органів малого таза, головного мозку з внутрішньовенним підсиленням, висновок: “Двобічна пневмонія в стадії зворотного розвитку. Ознаки кардіомегалії, легеневої гіпертензії. Проста кіста лівої нирки”. Хвора продовжувала отримувати інтенсивну посиндромну терапію, проте - без покращення, стан залишався тяжким. 25.04.20 р. у пацієнтки виник нестерпний біль у животі. Виконано ультразвукове дослідження органів черевної порожнини, заключення: “УЗД-ознаки застійного жовчного міхура, хронічного холециститу, хронічного пієлонефриту (загострення)". Виконано оглядову рентгенограму органів черевної порожнини, висновок: “Кишкова непрохідність”. Хвору оглянув хірург 8-ї лікарні, після чого з підозрою на гостру кишкову непрохідність, перитоніт та підозрою на коронавірусну хворобу SARS-CoV-2 COVID-19, ускладнену пневмонією, перевели в хірургічне відділення Криворізької міської лікарні № 7, перепрофільованої під приймання хворих із підозрою на нову коронавірусну інфекцію COVID-19.

Status praesens communis: загальний стан хворої вкрай тяжкий. Рівень свідомості - помірне оглушення. Положення пасивне, лежаче. Хвора підвищеного живлення. Шкірні покриви бліді з землистим відтінком. Молочні залози симетричні, соски не втягнуті, без виділень. У нижньовнутрішньому квадранті правої молочної залози пальпується дрібночасточкове ущільнення близько 5x3x4,5 см, помірно рухоме, пахвинні лімфовузли не збільшені. У легенях дихання везикулярне $з$ жорстким відтінком, ослаблене в нижніх відділах, спостерігають вологі різнокаліберні хрипи з обох сторін. ЧДР-22/хв. Тони серця приглушені, часті, ЧСС-96/хв, АТ-100/60 мм рт. ст., t-36,7 ${ }^{\circ} \mathrm{C}$.

Status localis: язик сухий, обкладений білим нашаруванням. Живіт піддутий, в акті дихан- ня участі не бере, напружений “дошкоподібно”. При пальпації різко болючий на всьому протязі, глибокій пальпації не досяжний, різко позитивний симптом Щоткіна-Блюмберга. При перкусії - тимпаніт, печінкова тупість збережена, спостерігається притуплення в бічних фланках. Перистальтика кишечника не прослуховується, “шум плескоту”. У встановленому трансуретрально катетері сеча відсутня.

Загальний аналіз крові (25.04.20р.): $\mathrm{Hb}$ 142 г/л, Er 4,6×1012/л, КП 0,92,

L 40,4х10 \%/л, юні - 6 \%, мієлоцити - $1 \%$, еозинофіли - $1 \%$, паличкоядерні - $31 \%$, сегментоядерні - $46 \%$, лімфоцити - 8 \%, моноцити - $7 \%$, ШОЕ - 3 мм/год.

Cito-test на антитіла до ВІЛ: антитіла до ВІЛ не виявлено.

Загальний аналіз сечі (25.04.20 р.): питома вага 1015, L 4-5 в п/3, Er незм. 25-30 у п/3, Er зм. 2-3 у п/з, білок - 0,242, кетонові тіла слабопозитивні (1+), епітелій перехідний 2-3 у п/3, циліндри зернисті 1-2 у п/3.

Біохімічний аналіз крові (25.04.20р.): білірубін загальний - 12,65 ммоль/л, прямий 8,05 ммоль/л, непрямий - 4,6 ммоль/л, загальний білок - 46,02 г/л, амілаза - 36,0 мг/год х мл, фібриноген - 4,2; ПТІ $90 \%$.

На підставі скарг, даних анамнезу та об'єктивного дослідження встановлено діагноз: гострий перитоніт невідомої етіології. Інтоксикація. СПОН.

Супутня патологія. Підозра на коронавірусну хворобу SARS-CoV-2 COVID-19. Двобічна позалікарняна пневмонія. ДН 1 ст. Хронічний пієлонефрит у стадії загострення, хронічна ниркова недостатність 3 ст. Інтоксикаційна енцефалопатія. Захворювання правої молочної залози?

Після медикаментозної підготовки та стабілізації життєвих функцій 25.02.20 р. о 16.50 хворій виконали операційне втручання: діагностична лапаротомія, під час якої в черевній порожнині виявлено близько 800 мл серозного тьмяно-жовтуватого випоту з неприємним запахом та поодинокими пластівцями фібрину, випіт рівномірно розподілений у черевній порожнині. Запально-деструктивні зміни органів черевної порожнини, які б могли спричинити розвиток перитоніту, відсутні. Виконано санацію, дренування черевної порожнини. Слід вказати, що згідно з даними останніх англомовних хірургічних часописів, при необхідності операції хворих на COVID-19 перевагу віддають лапаротомії, оскільки під час лапароскопії більший ризик вірусного аерування, внаслідок накладання пневмоперитонеуму. У післяопераційному періоді хворій продовжили інтенсивну посиндромну терапію в умовах відді- 
лення реанімації. Хвора перебувала на продовженій ШВЛ, гемодинаміка нестабільна, утримувалася медикаментозно. Незважаючи на проведення лікування, стан хворої залишився вкрай тяжкий. На тлі виражених проявів СПОН, інтоксикації 26.04 .20 р. о 10.06 наступила зупинка кровообігу, діагностовано клінічну смерть. Розпочато реанімаційні заходи, що не мали успіху. 26.04.20 p. о 10.36 констатовано біологічну смерть.

27.04.2020 р. було виконано патологоанатомічний розтин.

28.04.20 р. отримано відповідь ПЛР на вірус SARS-CoV-2 COVID-19 від 25.04.20 р. - результат позитивний. Після перегляду гістологічних препаратів хворої В. головним патологоанатомом міста і області, а також на кафедрі патологічної анатомії ДДМА встановлено остаточний діагноз.

Патологоанатомічний діагноз:

Основний: коронавірусна інфекція 2019 (ПЛР на вірус SARS-CoV-2 COVID-19 від 25.04.20 р. позитивний) / двобічна геморагічна тотальна пневмонія.

Ускладнення основного: інтоксикація. Генералізоване порушення мікроциркуляції з ДВЗ синдромом - тромби в дрібних судинах легень, інфаркти селезінки, некротичний нефроз, серозно-фібринозний перитоніт (операція 25.04.20 р. - лапаротомія, ревізія, санація, дренування черевної порожнини). Набряк легень. Венозне повнокрів’я.

\section{СПИСОК ЛІТЕРАТУРИ}

1. Clinical features of patients infected with 2019 novel coronavirus in Wuhan, China / C. Huang, Y. Wang, X. Li [et al.] // Lancet. - 2020. - Vol. 395. - P. 497-506. - Access mode : https://doi. org/10.1016/s0140-6736(20)30183-5

\section{REFERENCES}

1. Huang, C., Wang, Y., Li, X., Ren, L., Zhao, J., Hu, Y., et al. (2020). Clinical features of patients infected with 2019 novel coronavirus in Wuhan, China. Lancet, 395, 497-506. Retrieved from: https://doi.org/10.1016/s0140-6736(20)30183-5
2. Suspected acute abdomen as an extrapulmonary manifestaMartin [et al.] // Gir. Esp. - 2020. - Vol. 98 (5). - P. 295-296.

3. Case report: COVID-19 masquerading as an acute surgical abdomen / A. O. E. Ahmed, M. Badawi, K. Ahmed [et al.]. - 2020.

2. Blanco-Colino, R., Vilallonga, R., Martin, R. (2020). Suspected acute abdomen as an extrapulmonary manifestation of Covid-19 infection. Gir. Esp., 98, 295-296.

3. Ahmed, A.O.E., Badawi, M., \& Ahmed, K. (2020). Case report: COVID-19 masquerading as an acute surgical abdomen.

Отримано 06.01.2021
Супутній: XIXC: дрібновогнищевий кардіосклероз; жировий гепатоз; гострий геморагічний нефрит; фіброзна мастопатія.

обити такі висновки:

1. Перитоніт не зумовлений гострою запально-деструктивною патологією органів черевної рожнини.

го перебігу нової коронавірусної хвороби SARSCoV-2 COVID-19 у термінальній ї̈ стадії та є безпосереднім її наслідком.

кретному випадку COVID-19 є як легеневим за порагічну тотальну пневмонію), так і позалегеневим. COVID-19 - асоційованого перитоніту, імовірно зумовлений тромботичними причинами, які можпатогістологічного дослідження: тромби в дрібних судинах легенів, інфаркти селезінки, некрочний нефроз). ант перебігу нової коронавірусної хвороби SARSCoV-2 COVID-19.
Даний випадок не типовий та унікальний варі- 


\section{A.YU. GOROLYUK}

Kryvyi Rih City Hospital No. 7 of Kryvyi Rih Regional Council

\section{SEROUS FIBRINOUS PERITONITIS AS A CASUISTIC CLINICAL MANIFESTATION OF THE NEW CORONAVIRUS DISEASE SARS-COV-2 COVID-19}

The aim of the work: to indicate a rare case of peritonitis as a casuistic manifestation of the new coronavirus disease SARS-CoV-2 COVID-19.

Key words: coronavirus disease SARS-CoV-2 COVID-19; peritonitis; serous fibrinous peritonitis.

А. Ю. горолюк

КНП "Криворожская городская больница № 7" КГС

СЕРОЗНО-ФИБРИНОЗНЫЙ ПЕРИТОНИТ КАК КАЗУИСТИЧЕСКОЕ КЛИНИЧЕСКОЕ ПРРОЯВЛЕНИЕ НОВОЙ КОРОНАВИРУСНОЙ БОЛЕЗНИ SARS-COV-2 COVID-19

Цель работы: указать на редкий случай развития перитонита как казуистического проявления новой коронавирусной болезни SARS-CoV-2 COVID-19.

Ключевые слова: коронавирусная болезнь SARS-CoV-2 COVID-19; перитонит; серозно-фибринозный перитонит. 